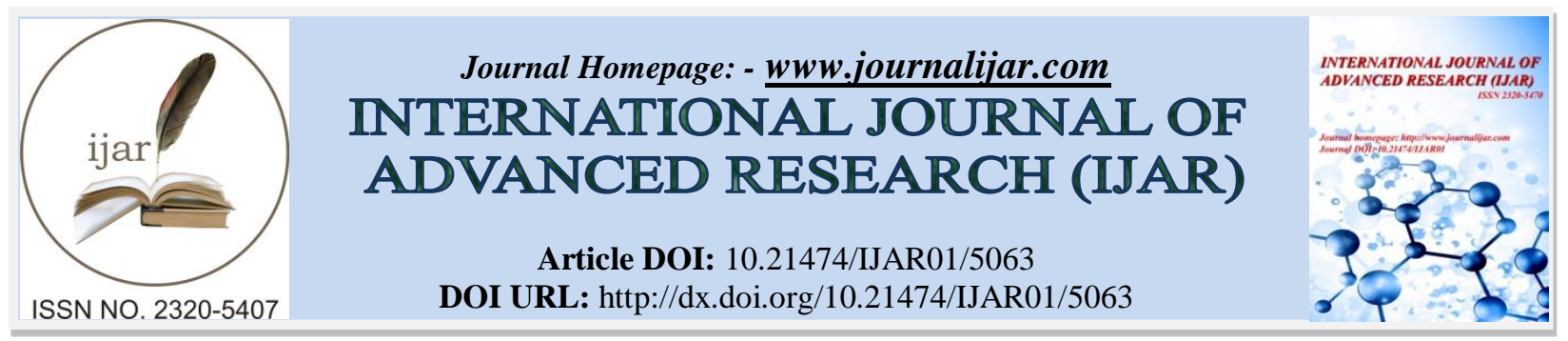

RESEARCH ARTICLE

\title{
VALUE RELEVANCE OF INTERNATIONAL FINANCIAL REPORTING STANDARDS (IFRS) AND SHAREHOLDERS' WEALTH MAXIMISATION: EVIDENCE FROM BANKS IN GHANA.
}

Isaac Cliford Queku.

$\mathrm{PhD}$ (Candidate), Accra Institute of Technology-Open University of Malaysia.

\section{Manuscript Info}

Manuscript History

Received: 04 June 2017

Final Accepted: 06 July 2017

Published: August 2017

Key words:-

Value relevance, Shareholders' wealth maximisation, IFRS multidimensional model, IFRS accounting quality, Mandatory disclosure, Voluntary disclosure and Presentational faithfulness

\section{Abstract}

The paper estimated value relevance of IFRS compliance of banks in Ghana from the perspective of shareholders. Queku's fourmultidimensional model was used to measure IFRS compliance. To achieve the stated objective, the paper formulated univariate models, two-variable models, three-variable and four-variable models for the investigations. Audited financial statements of sampled Ghanaian banks were the main source of data from 2008 to 2014. Predictive approach and coefficient of determination were the main approaches employed in the estimations. It was found that IFRS compliance has value relevance to shareholders of banks in Ghana. Implication of this finding is that IFRS based financial statements provide accounting data relevant to predicting shareholders' wealth of the banks. It also revealed that although the predictive models of all the IFRS constructs were significant; IFRS accounting quality which is one of the most widely cited construct of IFRS compliance was found to be irrelevant in this paper. The irrelevance of accounting quality evident in the study may reflect weakness in some recognition and measurement criteria of IFRS as it is measured directly from the financial statements. It is recommended that institute of chartered accountants Ghana should review the recognition and measurement criteria of each IFRS to determine whether or not adjustments are required to their implementation. The value relevance studies only show the predictive power, therefore future researchers should use the multidimensional model to estimate the direction of value relevance of each of the constructs so as to determine the economic consequence of this value.

Copy Right, IJAR, 2017,. All rights reserved.

\section{Introduction:-}

The attention on value relevance of information content of accounting data is in ascendency in recent times. Accounting researchers are developing strong interest in this research area. The value relevance studies in accounting literature take their root from the capital market-based accounting studies (Adetunji, 2016). The concept of value relevance depicts the degree of statistical relationship that exists between information provided by the financial statements and other key performance indicators such as the market value of equity or returns or shareholders' value (Barth, Beaver, \& Landsman, 2001; Beisland, 2008). 
One key parameter that determines the content of accounting data is the nature and characteristics of the accounting standards in used. Thus, the value relevance can be extended to evaluate compliance with a particular accounting standard. One type of accounting standard which is gaining global acceptance is International Accounting Standards (IAS)/ International Financial Reporting Standards (IFRS). It is a set of accounting standard developed by International Accounting Standard Board (IASB) as global accounting standard for preparing financial reports of companies and firms. Kunle, Omoruyi, and Hamed (2011) explained that IFRS promotes understandability, reliability, relevance and comparability of financial reports. These characteristics harness the value relevance of IFRS. According to Benzacar (2008), IFRS makes adopters internationally relevant and compete favourably within the global context for funds. Financial statements under IFRS apart from stating the financial position and performance of a firm or entity, provides other information such as the value added, changes in equity if any and cash flows of the enterprise within a defined period time to which it relates (Iyoha \& Faboyede, 2011) and detailed disclosures to transparently support stakeholders decisions. The relevance of financial reporting under IFRS is indispensable (Okpala, 2012). Furthermore, Garuba (2011) highlighted the value relevance of IFRS when the author argued that it is glaring that countries and companies can realise fully the gains in this era of globalisation and integration when they embrace the extant of IFRS.

These assertions seem to suggest that IFRS compliance has obvious value to adopters. However, Armstrong, Barth, Jagonlinzer and Riedl (2007) argued that the existing generally accepted accounting principles (GAAP) remain the golden standards and any effort to fully embrace IFRS could lead to value lost and sacrifice of quality. Some studies as cited in Queku (2016) have argued that there is no conclusive evidence that IFRS compliance has contributed to improving finnacial reporting system and accounting quality of adopters (Barth et al, 2008; Bartou et al, 2005). This group explained that one set of accounting standards cannot accommodate the differences in national practices of business arising from institutional and cultural diversity (Access Bank, 2010; Armstrong et al, 2007). Given these controversies about the relevance of IFRS compliance, it is timely for studies to be conducted to quantitatively evaluate the value relevance of IFRS compliance.

According to Heiberg (2014) the value relevance of IFRS could be assessed from perspectives of key actors of adopters including shareholders, lenders, the earning powers and cash flow management. One key stakeholder whose interest has often been used as benchmark to evaluate the value relevance of IFRS compliance is shareholders (Bueide \& Heiberg, 2014; Vafaei, Taylor \& Ahmed, 2011). However, the empirical results have been inconclusive. For instance whiles, Vafael et al (2011), did not find evidence of value relevance of IFRS compliance, Bueide and Heiberg (2014) found evidence of some sort. The mixed results could be attributed to the method used in evaluating the value relevance. These prior studies used comparison of performance ratios between IFRS based reporting and non-IFRS based reporting as the basis to estimate the value relevance of IFRS compliance.

Ratios are typically affected by events, economic situation within the industry and firms and management decisions and these carry their own noise about value relevance. Similarly, adjusting accounting data prepared under one set of accounting standards to ascertain financial results for another set of accounting standards may also be misleading as management decision including investment policy could be influenced by the actual set of accounting standards in used and these could not be reflected in the adjusted data. For instance, it is believed that the timely or early loss recognition characteristics of IFRS makes management more prudent and efficient in investment decision as their inefficiencies could easily be exposed if they invest in projects with negative net present value (NPVs) due to their inability to defer expenses or losses under IFRS. Thus, accounting data under IFRS would reflect this qualitative data which could not be captured in quantitative terms when adjusting accounting data prepared under non-IFRS are converted to IFRS for comparison. Therefore, to objectively evaluate the value relevance, alternative approach capable to avoid these deficiencies should be employed. This paper borrows the value relevance approach often used in accounting literature to assess value relevance of data to the capital market. It also employs Queku's multidimensional model to measure IFRS compliance quantitatively and subsequently evaluate the coefficient of determination of the constructs of IFRS. This paper seeks to use data from Ghanaian banks as the industrial fully migrated to IFRS since 2008. Thus, investigating the value relevance of IFRS from the perspective of shareholders of banks in Ghana would provide exciting evidence.

The choice of Ghana is influenced by the fact that it is one of early adopters of IFRS in Africa with the banking sector being the industry which has wholesomely migrated since 2008. The 2004 - World Bank report on accounting and auditing in Ghana painted a gloomy picture on Ghana in respect of its financial reporting and auditing. The World Bank stated that the accounting and auditing practices in Ghana suffer from institutional weaknesses in 
regulation, compliance and enforcement of standards and rules. Various weaknesses were identified in the laws and regulation governing financial reporting (ROSC-Ghana, 2004, p1). The report recommended full adoption of IFRS to improve quality financial reporting and value for investors. In line with the World Bank report coupled with International Federation of Accountants (IFAC) recommendations to the Institute of Chartered Accountants, Ghana (ICAG), in January, 2007, Ghana officially announced the launching of Ghana's adoption of IFRS and subsequent replacement of the Ghana National Accounting Standards (GNASs). The banks in Ghana have fully implemented IFRSs since the Ghana's adoption. It is therefore important to assess the value relevance of the IFRS adoption especially from the perspective of shareholders so as to provide evaluative empirical evidence to support or provide otherwise the decision for such wholesome adoption.

\section{Literature Review and Hypothesis Development:-}

Capital needs theory is one of the theories that predict the relationship between IFRS adoption and performance. The theory was proposed by F. D. S. Choi in 1973. Although the original capital needs theory primarily discusses voluntary disclosures, it has been extended to cover mandatory disclosures and accounting quality in literature (Tsalavoutas, 2009). The theory suggests that high level of informative reporting, disclosures and accounting quality reduce the cost of debt of adopters (Abd-Elsalam, 1999). Since cost of debt is earning deductible, any decrease in cost of debt would increase the residual earnings and maximise the wealth of shareholders. It can be hypothesised that:

$H_{1}$ : Accounting quality of IFRS, mandatory disclosures, mandatory disclosures and presentational faithfulness have significant value relevance to shareholders of Ghanaian Banks

Another theoretical basis to assume value relevance of IFRS compliance to shareholders can be taken from the agency theory. It is argued that managers' main goal is to maximise their personal goal to the extent that the principals are unaware and this is made easy by the separation of business ownership and the business control (Tsalavoutas, 2009). This argument supports the agency theory provision and assertion made by Morris (1987). According to Morris (1987), shareholders' goal can be met when there are monitoring mechanisms to check managers. Therefore, to mitigate the aberrant activities of the agents (managers) and reduce the cost, transparent and informative communication is required between the principals (shareholders) and the agent (managers).

It can therefore be argued that if managers are caused to provide quality accounting information, enhance their disclosures (i.e. mandatory and voluntary), abide by presentational faithfulness, they will be compelled to work towards achieving goal congruence since actions and inactions by managers can easily be traced by shareholders. This will ultimately reduce the monitoring cost by shareholders and bonding cost by managers (Nermeen, 2014, p.19). This will ultimately reduce operation expenses. The IFRS has the objective to harmonise International Financial Reporting through quality financial information, presentational comparability and extensive disclosures (Choi, Forst \& Meek, 2007; IFRS Insight: IASplus, 2008). This implies that IFRS compliance has the potential to reduce the agency cost such as monitoring cost, bonding cost and residual loss as stated by Jensen and Meckling (1976). Thus, the earlier hypothesis $\left(\mathrm{H}_{1}\right)$ that accounting quality of IFRS, mandatory disclosures, mandatory disclosures and presentational faithfulness has significant value relevance to shareholders of Banks in Ghana is also confirmed by this theory.

The theoretical arguments suggest strong economic benefits and direct contribution of IFRS compliance to shareholders and therefore have strong value relevance. However, a review of value relevance literature shows that a prominent characteristic in most of the previous studies on value relevance of accounting information is a failure to distinguish between accounting standards that are used and those that are actually implemented. Notwithstanding any form of failure that non-compliance of the IFRS may bring to certain economies or business entities, its value relevance could be seen in many actors and financial performance benchmarks. Some of these actors include shareholders, lenders, the earning powers and cash flow management (Heiberg, 2014).

In their quest to investigate value relevance of IFRS Vafaei, Taylor and Ahmed (2011) took a sample of 150 randomly selected firms listed on three Stock Exchanges (i.e. London, Hong Kong and Singapore) for the year of adoption of IFRSs (2005). The study investigates whether the quality of accounting figures (earnings per share and book value of equity) has improved as a result of adoption of IFRSs in UK, Hong Kong and Singapore. With regards to value relevance, results indicate no improvement in the value relevance of accounting figures as a result of adoption of IFRSs within the sampled countries. Additionally, the results indicate that the extent of adjustments 
made and the costs of transition incurred in UK for first-time adoption of IFRSs are greater than the adjustments made and the costs incurred in Hong Kong and Singapore.

Assessing the value relevance of IFRS from the shareholders perspective, Bueide and Heiberg (2014) investigated to find out whether the association between IFRS accounting numbers and stock market values is stronger than those reported under Norwegian GAAP (NGAAP). In their study they took a sample of 145 firms listed on Oslo Stock Exchange. The firms reported financial statement in accordance to NGAAP in 2004 and restated those reports when adopted IFRS in 2005. Results of the study provide little evidence of increased value relevance after adoption of IFRS when comparing and evaluating two regimes separately. In contrast, when changes in the accounting numbers from NGAAP to IFRS are examined, the results indicate that reconcilement adjustments to IFRS are marginally value relevant, which is due to increased relevance of the balance sheet and the normalized net income. The increment of the bank sheet and net income through the standardised use of the IFRS is an indication that shareholders of such listed companies are set to benefit from the payment of high dividends with regards to their individual shares.

Comparing the findings by Bueide and Heiberg (2014) and that of Vafaei, et al (2011), it could be observed that at one breadth, the use of IFRS is beneficial to shareholders while on the other hand it may provide little value for shareholders. Besides the mixed results, the method of investigating the value relevance has strong limitations. The studies above used comparison of performance ratios between IFRS based reporting and non-IFRS based reporting, restatement of accounting data and adjustment from one set of standard to another.

These approaches (ratio comparison and reconciliation) are affected by events, economic performance of the country and industry per the given time and managerial decisions and policy which could make the true relevance and irrelevance obscured. Further, using the reconciliation method where the accounting data from one set of accounting standard is adjusted to ascertain comparable accounting data under another set of accounting standards may also be misleading as management decision such as investment policy could be influenced by the actual set of accounting standards of the firms' in question. For instance, IFRS adoption does frown over deferment of losses and mandates early and timely recognition. Consequently, to keep their reputation and demonstrate efficiency and prudence, managers of companies adopting IFRS are likely to be more inclined to efficiency in investment decision and would found it not rewarding to undertake negative net present value (NPV) projects. Thus, they would likely consider only positive NPV projects. Thus, financial statements under IFRS would reflect this qualitative data which would ordinarily not be captured when IFRS accounting data is prepared as reconciliation from accounting data prepared under non-IFRS. Therefore, value relevance studies require superior approach. This paper does not only fill the unexplored value relevance study in the Ghanaian accounting literature but also contributes to methodology for IFRS value relevance in broad context. For comparability, the paper extrapolates the value relevance estimation approach adopted in accounting literature on the capital market.

Estimation of value relevance in accounting literature has evolved over time. The current multivariate predictive approach can be traced to studies such as Beaver, Kettler and Scholes (1970), Eskew (1979) and Elgers (1980). These earlier value relevance based studies measure value relevance as the degree of predictability and therefore uses the coefficient of determination as the basis. Hilton and Stone (1980) and Kothari and Sloan (1992) have been major contributors to the multivariate predictive approach to value relevance. These researchers have argued that to determine the value relevance using the multivariate approach, control variables should not be introduced as they could serve as noise to overestimate the value relevance. Thus, to avoid this problem only the relevant predictors are introduced into the model. The challenge with this approach is the difficulty in selecting the true predictors relevant to estimate the value relevance. Researchers in empirical studies have often used method such as trial and error, intuition and reliance on prior empirical results (Brimble, 2003). These concerns were echoed in studies such as Lavern, Durinck, De Ceuster \& Lybaek (1997) and Ryan (1997). The paper would manage these challenges using evidences in IFRS literature.

\section{Data, Sources and Description of Variables:-}

Quantitative analytical approach and causal design is used in this paper. This analytical procedure and design is suitable as the paper seeks to establish cause and effect relationship between IFRS compliance and shareholders' wealth maximisation (Cresswell, 2009). Secondary data from 2008 to 2014 are used. These are collected from audited financial statements of Banks in Ghana within the sample. Twenty (20) banks were used for the study. 
The key study variables are IFRS compliance which serves as the predictor and the shareholders wealth maximisation which constitutes the dependent variable. The paper uses Queku's four-multidimensional model to measure IFRS compliance (Queku, 2016, 2017). Queku's four-multidimensional model is as follow:

$$
4-I F R S_{\text {lct }}=w_{1} A Q_{t}+w_{2} M D_{t}+w_{3} V D_{t}+w_{4} P f_{t}
$$

Where:

4-IFRS ${ }_{\text {ict }}$ is the four- four-multidimensional model

$\mathrm{AQ}$ is the accounting quality

MD is mandatory disclosure

VD is voluntary disclosure

Pf is presentational faithfulness or framework

This model would address the challenge of selecting the appropriate predictors in the multivariate approach to value relevance assessment (Lavern et al, 1997; Ryan, 1997). This four-multidimensional model has been validated and tested in the study of Queku (2017). The accounting quality is measured using the accrual method. The accrual method uses the deviation between earnings and operating cash flows within a given financial year to estimate accounting quality (Queku, 2017). Heidi (2012) as cited in Queku (2017) explained that accrual method measures accounting quality by the difference between the net income and operating cash flow scaled by the average total assets. This cash flow based method is very suitable for the banking sector as liquidity is a key benchmark for assessing relevance of a policy (Queku, 2017).

The disclosure variables: mandatory disclosure, voluntary disclosure and presentational faithfulness are measured using self-constructed indices. Where applicable, the 'Partial Compliance unweighted approach' used by Al-Shiab (2008) and Street and Gray (2001) is employed in this study. The present paper frowns over the unweighted approach on the following ground: all standards do not have equal number of items to comply. Whiles some require more items of compliance (e.g. IAS 1), others also requires only few (e.g. IAS 2). Therefore summing up the individual required compliance under all the standards implies that those with more items are treated superior to those with few ones. In order to avoid this bias, the paper employs the partial compliance unweighted approach.

The mandatory disclosure index was constructed from relevant IFRS/IAS similar to the procedures adopted in the study of Tsalavoutas (2009). The voluntary disclosure index was also constructed from a modified version of Hubert and Heger (2011). The presentational faithfulness or framework index was constructed mainly from IAS 1 and IAS 30 subordinated by other relevant standards.

The dependent variable (Shareholders' wealth maximisation) is measured as earnings after tax and preference dividend over shareholders value. This represents ROE. It is mathematically presented as:

$$
\text { Shareholders Value }(S V)=\frac{\text { Earnings after tax }- \text { Preference dividends }}{\text { Shareholders fund }+ \text { Reserves and Surpluses }}
$$

\section{Model Specification:-}

The reviewed theories predict a causal relationship between IFRS compliance and shareholders' wealth maximisation of Banks. There are wide range of theories that provide theoretical relationship between IFRS compliance and shareholders' wealth maximisation. The popular theories reviewed include capital needs theory, agency theory and proprietary theory. Following the focus of this paper and the data availability, the paper builds its empirical model from panel model to explain the value relevance of IFRS compliance and shareholders' wealth of banks in Ghana.

Panel model combines the data characteristics of both time-series and cross-sectional data. Panel model pools data from cross-sections over several periods (Bayeh, 2011). It has been established in the literature that panel data have two estimation specifications for determining its coefficients. According to Brook (2008), these coefficients estimation models are panel random effect model and panel fixed effect model. The paper does not arbitrary choose the effect specification rather it would follow Hausman approach (Hausman, 1978). The general theoretical model under the panel fixed effect for this study is presented as:

$$
Y_{i t}=\alpha_{i}+\beta_{1} X_{i t}+\varepsilon_{i t}
$$


Where:

The subscript ' $\mathrm{i}$ ' and' $\mathrm{t}$ ' represent the cross-sectional dimension (Ghanaian banks) and time-series dimension (years) respectively.

' $Y$ ', represents the dependent variable of the study

' $\mathrm{X}$ ' represents the independent variables

' $\beta$ ' is the constant of the model and represents the coefficients of the independent variables

$\varepsilon_{i t}$ is the error term.

To test the value relevance of the IFRS compliance for shareholders, the multidimensional models are employed. This is also seen as further test of the multidimensional estimation model, the paper would use single construct, two dimensional constructs, three dimensional and four dimensional constructs. This approach would not only provide evidence of value relevance of IFRS compliance but also relevance of the multidimensional model for estimating IFRS compliance. The hypothesis is restated as follows:

\section{$H_{1}$ : IFRS compliance has significant value relevance for shareholders of Ghanaian Banks.}

The following models have therefore been expressed to test this hypothesis: The models (4) to (7) test the value relevance of IFRS compliance based on single construct (SC) measures by Accounting Quality (AQ), Mandatory Disclosure (MD), Voluntary Disclosure (VD) and Presentational Faithfulness or Framework (PF). Thus, the SC is replaced with $\mathrm{AQ}, \mathrm{MD}, \mathrm{VD}$ and $\mathrm{PF}$ in turns.

$$
\begin{aligned}
& R O E_{i t}=\alpha_{i}+\beta_{1} A Q_{i t}+\varepsilon_{i t} \\
& R O E_{i t}=\alpha_{i}+\beta_{1} M D_{i t}+\varepsilon_{i t} \\
& R O E_{i t}=\alpha_{i}+\beta_{1} V D_{i t}+\varepsilon_{i t} \\
& R O E_{i t}=\alpha_{i}+\beta_{1} P F_{i t}+\varepsilon_{i t}
\end{aligned}
$$

The study introduces each of the constructs into the single model to derive the two-multidimensional models and check the relevance of the additional IFRS dimension.

$$
\begin{aligned}
& R O E=\alpha_{i}+\beta_{1} A Q_{i t}+\beta_{2} M D_{i t}+\varepsilon_{i t} \\
& R O E=\alpha_{i}+\beta_{1} A Q_{i t}+\beta_{2} V D_{i t}+\varepsilon_{i t} \\
& R O E=\alpha_{i}+\beta_{1} A Q_{i t}+\beta_{2} P F_{i t}+\varepsilon_{i t} \\
& R O E=\alpha_{i}+\beta_{1} M D_{i t}+\beta_{2} V D_{i t}+\varepsilon_{i t} \\
& R O E=\alpha_{i}+\beta_{1} M D_{i t}+\beta_{2} P F_{i t}+\varepsilon_{i t} \\
& R O E=\alpha_{i}+\beta_{1} V D_{i t}+\beta_{2} P F_{i t}+\varepsilon_{i t}
\end{aligned}
$$

Further variables are introduced into the two- multidimensional models to form three-multidimensional models. It is believed that if this dimension is also relevant the explanatory power would be improved and hence the value relevance.

$$
\begin{aligned}
& R O E_{i t}=\alpha_{i}+\beta_{1} A Q_{i t}+\beta_{2} M D_{i t}+\beta_{3} V D_{i t}+\varepsilon_{i t} \\
& R O E_{i t}=\alpha_{i}+\beta_{1} A Q_{i t}+\beta_{2} M D_{i t}+\beta_{3} P F_{i t}+\varepsilon_{i t} \\
& R O E_{i t}=\alpha_{i}+\beta_{1} A Q_{i t}+\beta_{2} V D_{i t}+\beta_{3} P F_{i t}+\varepsilon_{i t}
\end{aligned}
$$

Finally, the three-multidimensional models are transformed to a four-multidimensional model of IFRS compliance. This is as:

$$
R O E_{i t}=\alpha_{i}+\beta_{1} A Q_{i t}+\beta_{2} M D_{i t}+\beta_{3} V D_{i t}+\beta_{4} P F_{i t}+\varepsilon_{i t} \text { (17) }
$$

Where $\mathrm{ROE}_{\text {it }}$ measures shareholders' value and represents return on equity

The rest of the variables have already been defined. 


\section{Estimation Technique:-}

Having determined the models for investigating the value relevance of IFRS compliance from the shareholders' perspective, the paper subsequently uses appropriate regression estimator to run the data. This paper uses Generalised Method of Moment (GMM) to conduct the estimations. The Generalized Method of Moments (GMM) is a statistical estimation technique that combines the observed economic data with the data or the information contains in the population moment conditions to produce estimates of the unknown parameters of the relevant models of interest. GMM is one of the most widely used estimation technique for panel model (Chaussé, 2010).

The choice of GMM as the main estimation technique for the models in this study is influenced by certain factors and reasons. One of the reasons for choosing GMM is the fact that GMM has relatively limited assumption unlike other econometric estimators and this makes GMM estimator easy to use and convenient (Garcia, Nielsen \& Nock, 200). It is capable to handle and analyse unknown parameters which are not captured in the sample moments making the results and estimates quite robust (Zhohar, 2012). This also provides general solution which approximates the population and enhances extrapolation and generalization of the findings, conclusions and applications of the evidence.

\section{Econometric Consideration:-}

Prior to conducting the estimation using Generalised Method of Moment (GMM) estimator, the paper first conducts some basic econometric diagnostics to ensure that the models estimated are robust. To achieve this robustness of the models estimation, the data used in the models should be suitable and appropriate. The suitability tests require investigation on some basic econometric considerations such as unit root, multicollinearity, heteroscedasticity, and autocorrelation. Besides these diagnostics, since the econometric models to be estimated are panel models, Hausman test is required to determine the characteristics of the data set used so as to reveal whether it is fitting to estimate the fixed effect or random effect in the empirical analysis.

\section{Results and Discussions:-}

The paper uses the methodologies discussed to conduct the study. The paper conducts statistical analysis of the relevant data collected to measure the study variables in line with the focus of this research. The scope of the empirical statistical analysis and extent of the application of the research methodologies are determined by the specific research objective, and hypotheses developed through the literature review. The results are presented in tables and discussed accordingly.

\section{Descriptive Analysis:-}

In order to empirical investigate the value relevance of IFRS compliance, key variables have been identified and measured. It is therefore quite essential to analyse the statistical properties and consistencies to add confidence to the research. The paper has analysed the descriptive statistics of these variables and reported the results in Table 1 . The descriptive statistics considered in this study are the mean, standard deviation, minimum and maximum values of the study variables used. These statistics are based on selected 20 banks in Ghana which have operated within the period of 2008 to 2014 due to the unavailability of data on some existing banks. The mean denotes the average value of the relevant variables whilst standard deviation shows how variables are distributed around their mean values.

Table 1:- Descriptive Statistics of Variables (2008 to 2014)

\begin{tabular}{|l|l|l|l|l|l|}
\hline & \multicolumn{1}{|c|}{ ROE } & \multicolumn{1}{c|}{ AQ } & MDI & VDI & PF \\
\hline Mean & 0.2136 & 0.4655 & 0.6819 & 0.5989 & 0.6230 \\
\hline Median & 0.1718 & -0.0385 & 0.7382 & 0.6277 & 0.6339 \\
\hline Maximum & 4.5481 & 70.7576 & 0.8767 & 0.8548 & 0.8571 \\
\hline Minimum & -1.2287 & -0.5673 & 0.1584 & 0.0212 & 0.4181 \\
\hline Std. Dev. & 0.4811 & 6.0289 & 0.1478 & 0.2110 & 0.0741 \\
\hline Observations & 138 & 138 & 138 & 138 & 138 \\
\hline
\end{tabular}

Source: Queku (2017): Computed from Eviews 7 Package

The average value of return on equity which is used in this paper as proxy for shareholders' wealth is 0.2136 and median statistics of 0.1718. From the table, Return on Equity (ROE) fluctuates from a maximum of 4.5481 to a minimum of -1.2287 with a standard deviation of 0.4811 . 
From the table, it has been revealed that the accounting quality (AQ) of the banks is relatively low on an average (mean). The mean value is 0.4655 with median of -0.0385 . The range however, is high. The maximum value of AQ is 70.7576 and minimum value is -0.5673 . The high range of the data reflects the high level of standard deviation of 6.0289. The relatively low accrual level (high accounting quality) and to the extent of achieving negative observation seems to suggest that sample firms with high level of IFRS compliance are more likely to underestimate than overestimate their earnings relative to cash flows. The mean (median) value of mandatory disclosures (MDI) is 0.6819 (0.7382). This statistics is relatively high though falls short of the general expectation. This shows that on the average banks in Ghana respond positively to mandatory disclosure requirements. The range values are from 0.1584 to 0.8767 . The differences in observations mean that the banks within the sample do not respond equivalently to the mandatory disclosures. The standard deviation for the MDI mean statistics is also 0.1478 .

The mean (median) of the level of voluntary disclosures (VDI) is 0.5989 (0.6277). Compared to the MDI, the VDI has higher level of compliance in relative terms. This means that banks generally presents relevant additional information to stakeholders to enhance transparency. The minimum value and maximum value for this variable are 0.0212 and 0.8548 respectively. The standard deviation of the individual observations from the average (mean) is 0.2110 . Within the same study period (2008 to 2014), level of presentational framework or faithfulness as represented as PF in the Table above has a mean value (median) of $0.6230(0.6339)$. These statistics (mean and median) are very close signifying symmetric characteristics of the data. The data range from 0.4181 as minimum value to 0.8571 as the maximum value in the study period. The range statistics is relatively low compared to the rest of IFRS compliance indicators. The standard deviation associated with the mean statistics of presentational framework is 0.0741 . This is very low suggesting that the observations have low dispersion. The low range statistics and standard deviation can be explained that most of the banks prepare their financial statements to represent relatively the physique of IFRS requirements.

\section{Panel Unit Root Analysis:-}

Unit root test is considered generally as phenomenon of time series analysis; however, it is also expected to be conducted within the panel analysis due to the time series component of the panel series. Furthermore, testing unit root under panel also helps to prevent the possibility of estimating unrelated regressions and models. The paper therefore conducts the unit root tests to verify the stationarity property or order of integration of the selected variables so as to decide on appropriate and related estimation technique. The most widely used techniques for testing unit root are the Augmented Dickey Fuller (ADF) test and the Phillips-Perron test and these are used in this paper. Since it is possible to obtain conflicting results, the study uses Im, Pesaran and Shin W-stat (IPS) in addition to the ADF and PP. This would help to make potent decision on rejecting or fail to reject unit root problem. Decision rule for these tests is that when the probability value of the statistics of these techniques is less than the level of significance, the $\mathrm{H}_{0}$ is rejected with a conclusion that the variable is stationary and vice-versa. Table 2 presents the results of these unit root tests.

Table 2:- Stationarity Analysis of the Study Variables (2008-2014)

\begin{tabular}{|l|l|l|l|l|}
\hline & ADF & PP & IPS & Order \\
\hline ROE & $91.4678(0.0000)$ & $72.7628(0.0012)$ & $-34.2505(0.0000)$ & $\mathrm{I}(0)$ \\
\hline AQ & $52.2046(0.0936)$ & $129.392(0.0000)$ & $-5.7907(0.0000)$ & $\mathrm{I}(0)$ \\
\hline MDI & $20.3890(0.9442)$ & $39.2133(0.1778)$ & $1.6212(0.9475)$ & $\mathrm{I}(1)$ \\
\hline VDI & $37.9303(0.2171)$ & $43.7014(0.0814)$ & $-0.2153(0.4148)$ & $\mathrm{I}(1)$ \\
\hline PF & $73.5780(0.0010)$ & $70.5892(0.0020)$ & $-2.6890(0.0036)$ & $\mathrm{I}(0)$ \\
\hline
\end{tabular}

Note: The statistics in the parenthesis are the p-values

Source: Queku (2017): Computed from Eviews 7 Package

It can be seen from the Table 2 that the variables have mixed results regarding the unit root status. Whiles variables such as ROE, AQ and PF are stationary, MDI and VDI are non-stationary. Therefore GMM estimation could outperform ordinary least square as it is not suitable for unit root problem unless the research decides to difference the non-stationary variables which are not the focus of the paper. The paper seeks to analyse the data from levels not difference.

\section{Multicollinearity Diagnostic:-}

Multicollinearity problem is conducted using correlation matrix. Multicollinearity problem makes it difficult to assess the value relevance of the individual predictor, and thus, leads to unstable estimates of the values of the 
coefficient of the regression model. This problem is common in multivariate estimations which is the case in this paper. One means to determine the presence of multicollinearity problem is testing the correlation statistics (r) between predictors. According to Malhora (2007) when the coefficient of correlation is equal to or greater than 0.8 then it is an indication of multicollieneraity problem which need to be corrected. Table 3 reports the correlation matrix of the predictors.

Table 3:- Correlation Matrix of Predictors (2008-2014)

\begin{tabular}{|l|l|l|l|l|}
\hline & AQ & MDI & VDI & PF \\
\hline AQ & 1 & & & \\
\hline MDI & 0.0434 & 1 & & \\
\hline VDI & -0.0570 & 0.0721 & 1 & \\
\hline PF & 0.0676 & -0.0895 & -0.0315 & 1 \\
\hline
\end{tabular}

Source: Queku (2017): Computed from Eviews 7 Package

It can be observed from the Table 3 that there is no multicollinearity problem. The highest correlation coefficient from the Table is 0.0895 in absolute terms which is between MDI and PF. This suggests that all these predictors can be modelled in a single regression and be estimated.

\section{Value Relevance Estimation:-}

As discussed under the methodology, the paper applies value relevance (VR) estimation approach often used within the Capital Market-Based Accounting Research. Following earlier studies such as Adetunji (2016), Barth et al (2001) and Beisland (2008), the value relevance in this research measures the degree of statistical relationship that exists between information provided by IFRS complied financial statements and shareholders' value (Beisland, 2008; Barth, Beaver, \& Landsman, 2001). In conformity with the methodology, the main technique of the value relevance analysis used was regression and multivariate predictive approach. The higher the coefficient of determination as measured by $\mathrm{R}^{2}$, the higher the VR of the IFRS compliance for shareholders' value (Adetunji, 2016). The results for the Generalised Method of Moment estimation are provided in Table 4. It is observed from the results that the $R^{2}$ and adjusted $R^{2}$ of the models have a range of $0.233(0.183)$ to $0.537(0.506)$. The $R^{2}$ is outside the parenthesis whiles adjusted $\mathrm{R}^{2}$ is in the parenthesis. The table also reports the J-statistics. These statistics test the validity of instruments used in the models. When the J-statistics is closer to 1 , then there is a strong case of validity of the instruments or the moments used. The results revealed that the J-statistics of all the models are closer to 0 indicating the instruments or the moments used are valid.

The findings revealed that among the single construct models, model 4 (M4) has the least value relevance for shareholders' value of Banks in Ghana. This model depicts IFRS accounting quality (AQ). The AQ generate coefficient of determination of 0.233 and adjusted $\mathrm{R}^{2}$ of 0.183 . The construct of IFRS with the highest value relevance is mandatory disclosure with $R^{2}$ of 0.525 and adjusted $R^{2}$ of 0.494 representing the model five (M5), followed by voluntary disclosure with $\mathrm{R}^{2}$ of 0.514 and adjusted $\mathrm{R}^{2}$ of 0.482 as evident in model six (M6) and presentational faithfulness with $\mathrm{R}^{2}$ of 415 and adjusted $\mathrm{R}^{2}$ of 0.376 shown in model seven (M7). The findings show that each of the four constructs of IFRS uniquely has value relevance. This is important because accounting data is seen to be value relevant when the $\mathrm{R}^{2}$ and the adjusted $\mathrm{R}^{2}$ is greater than zero (0) (Babalola, 2012; Paglietti, 2009). Therefore, generating adjusted $\mathrm{R}^{2}$ of between $18.3 \%$ to $52.5 \%$ for univariate model (single variable predictability) demonstrate how relevant each of the IFRS construct developed in Queku's multidimensional model (Queku, 2016). The two-variable models also revealed strong value relevance to shareholders' of Banks in Ghana. The findings show that IFRS compliance two-variable models predict between $0.415(0.376)$ to $0.525(0.494)$ variation in shareholders' wealth. Thus, the models account for minimum of $37.6 \%$ to $52.5 \%$ of changes in shareholders' wealth maximisation. It can be observed that MDI and VDI in the model eleven (M11) have the highest value relevance to shareholders' wealth as they account for 0.525 (0.494)-49.4\% variation in shareholders' wealth. Another interesting finding is that though AQ has value relevance of about $18.3 \%$ on individual basis, however, could not have any significant effect on the value relevance in the two-variable models (see M8, M9 and M10 as found in Table 4).

Regarding the three-variable constructs or models, the value relevance of IFRS improved except the models with AQ whose value relevance remained as they were under the two-variable models. For instance, M11=M14 and M12=M15. Model sixteen (16) showed that MDI, VDI and PF contribute to about 50.6\% of changes in shareholders' wealth of banks in Ghana holding other factors constant. A similar value relevance estimate was found for model seventeen (M17). Thus, M17=M16 as the AQ could not significantly contribute to the value relevance. 
Table 4:- Value Relevance Estimates (2008-2014)

\begin{tabular}{|c|c|c|c|}
\hline VR Models & $\mathbf{R}^{2}$ & Adj. $\mathbf{R}^{2}$ & J-stat \\
\hline M4: $\mathrm{ROE}_{\mathrm{it}}=\alpha_{0}+\beta_{1} \mathrm{AQ}_{\mathrm{it}}+\varepsilon_{\mathrm{it}}$ & 0.233 & 0.183 & $1.41 \mathrm{E}-30$ \\
\hline M5: $\mathrm{ROE}_{\mathrm{it}}=\alpha_{0}+\beta_{1} \mathrm{MD}_{\mathrm{i}}+\varepsilon_{\mathrm{it}}$ & 0.525 & 0.494 & $4.88 \mathrm{E}-29$ \\
\hline M6: $\mathrm{ROE}_{\mathrm{it}}=\alpha_{0}+\beta_{1} \mathrm{VD}_{\mathrm{it}}+\varepsilon_{\mathrm{it}}$ & 0.514 & 0.482 & $1.74 \mathrm{E}-27$ \\
\hline M7: $\operatorname{ROE}_{\mathrm{it}}=\alpha_{0}+\beta_{1} \mathrm{PF}_{\mathrm{it}}+\varepsilon_{\mathrm{it}}$ & 0.415 & 0.376 & $9.30 \mathrm{E}-28$ \\
\hline M8: $\operatorname{ROE}_{\mathrm{it}}=\alpha_{0}+\beta_{1} \mathrm{AQ}_{\mathrm{it}}+\mathrm{MD}_{\mathrm{it}}+\varepsilon_{\mathrm{it}}$ & 0.525 & 0.494 & $1.18 \mathrm{E}-28$ \\
\hline M9: $\mathrm{ROE}_{\mathrm{it}}=\alpha_{0}+\beta_{1} \mathrm{AQ}_{\mathrm{it}}+\mathrm{VD}_{\mathrm{it}}+\varepsilon_{\mathrm{it}}$ & 0.514 & 0.482 & $5.92 \mathrm{E}-29$ \\
\hline M10: $\mathrm{ROE}_{\mathrm{it}}=\alpha_{0}+\beta_{1} \mathrm{AQ}_{\mathrm{it}}+\mathrm{PF}_{\mathrm{it}}+\varepsilon_{\mathrm{it}}$ & 0.415 & 0.376 & $3.38 \mathrm{E}-25$ \\
\hline M11: $\mathrm{ROE}_{\mathrm{it}}=\alpha_{0}+\beta_{1} \mathrm{MD}_{\mathrm{it}}+\mathrm{VD}_{\mathrm{it}}+\varepsilon_{\mathrm{it}}$ & 0.528 & 0.496 & $1.92 \mathrm{E}-24$ \\
\hline M12: $\mathrm{ROE}_{\mathrm{it}}=\alpha_{0}+\beta_{1} \mathrm{MD}_{\mathrm{it}}+\mathrm{PF}_{\mathrm{it}}+\varepsilon_{\mathrm{it}}$ & 0.534 & 0.503 & $2.84 \mathrm{E}-24$ \\
\hline M13: $\mathrm{ROE}_{\mathrm{it}}=\alpha_{0}+\beta_{1} \mathrm{VD}_{\mathrm{it}}+\mathrm{PF}_{\mathrm{it}}+\varepsilon_{\mathrm{it}}$ & 0.515 & 0.483 & $1.28 \mathrm{E}-24$ \\
\hline M14: $\mathrm{ROE}_{\mathrm{it}}=\alpha_{0}+\beta_{1} \mathrm{AQ}_{\mathrm{it}}+\mathrm{MD}_{\mathrm{it}}+\mathrm{VD}_{\mathrm{it}}+\varepsilon_{\mathrm{it}}$ & 0.528 & 0.496 & $6.30 \mathrm{E}-25$ \\
\hline M15: $\mathrm{ROE}_{\mathrm{it}}=\alpha_{0}+\beta_{1} \mathrm{AQ}_{\mathrm{it}}+\mathrm{MD}_{\mathrm{it}}+\mathrm{PF}_{\mathrm{it}}+\varepsilon_{\mathrm{it}}$ & 0.534 & 0.503 & $1.46 \mathrm{E}-24$ \\
\hline M16:ROE ${ }_{\mathrm{it}}=\alpha_{0}+\beta_{1} \mathrm{MD}_{\mathrm{it}}+\mathrm{VD}_{\mathrm{it}}+\mathrm{PF}_{\mathrm{it}}+\varepsilon_{\mathrm{it}}$ & 0.537 & 0.506 & $1.22 \mathrm{E}-23$ \\
\hline M17:ROE $\mathrm{it}_{\mathrm{it}}=\alpha_{0}+\beta_{1} \mathrm{AQ}_{\mathrm{it}}+\mathrm{MD}_{\mathrm{it}}+\mathrm{VD}_{\mathrm{it}}+\mathrm{PF}_{\mathrm{it}}+\varepsilon_{\mathrm{it}}$ & 0.537 & 0.506 & $1.63 \mathrm{E}-24$ \\
\hline
\end{tabular}

Note: VR denote value relevance, $\mathrm{R}^{2}$ is the coefficient of determination

Source: Queku (2017): Computed from Eviews 7 Package

These findings partly meet the paper's expectations and partially inconsistent with the apriori. This research expected each of the elements of IFRS compliance estimation to have significant contribution to value relevance of IFRS compliance to the level of shareholders' value or wealth on a standalone basis. This was met as each of the constructs of IFRS compliance has value relevance of greater than zero (0). However, whiles the mandatory, voluntary disclosures and presentational faithfulness met the expectations in the multivariate predictive models, accounting quality was insignificant.

The value relevance of the individual constructs: accounting quality, mandatory disclosure, voluntary disclosure and presentational faithfulness and multivariate predictive relevance of mandatory disclosure, voluntary disclosure and presentational faithfulness affirm the theoretical assumptions of capital needs theory and agency cost theory employed in this paper. Following the findings in this paper and given the capital need theory postulation, it can be explained that IFRS compliance has value relevance for shareholders' wealth maximisation as the compliance produces high level of informative, understandable, comparable, transparent and quality financial reports which could reduce risk of debt and therefore decrease the cost of debt of adopters (Abd-Elsalam, 1999; Tsalavoutas, 2009). The reduced cost of debt increases shareholders' returns holding other factors constant and ultimately maximises the wealth of shareholders.

Another explanation can be provided from the agency cost theory. Borrowing from Morris (1987), IFRS compliance carries value relevant to shareholders as it could be seen as monitoring mechanism by principals (shareholders) to check agents (managers) and to mitigate their (managers) aberrant activities and reduce the cost. This could enhance the earning power and wealth of shareholders. Based on this, any additional deepening in the level of IFRS compliance by banks in Ghana could translate into increasing shareholders wealth maximisation.

The insignificant value relevance of accounting quality to shareholders of banks in Ghana in the multivariate predictive models can be attributed to recognition and measurement criteria of IFRS compliance. Among the constructs of IFRS, it is only accounting quality that takes its measurement data from the face of the financial statements directly. The items standing on the face of financial statements are determined by the recognition and measurement criteria. Therefore, IFRS accounting quality is a direct determinant from IFRS recognition and measurement. The insignificant value relevance thus, suggests that some recognition and measurement criteria do not have significant value relevance in association with other constructs of IFRS. This finding could be a starting point evidence to quantitatively investigate full versus partial compliance of IFRS. It is possible that some of the recognition and measurement criteria undermine the value relevance of IFRS accounting quality and this requires further investigation. The low value relevance of IFRS accounting quality might also have been caused by the method used to measure accounting quality. 


\section{Conclusions and Recommendations:-}

This paper sought to estimate value relevance of IFRS compliance of banks in Ghana from the perspective of shareholders. To achieve the stated objective, the paper employed the four-multidimensional constructs of IFRS. The paper formulated univariate models to measure value relevance of each of the constructs on a standalone basis, two-variable models, three-variable and four-variable models to determine the value relevance as and when each additional constructs are complied with. Audited financial statements of sampled banks were the main source of data. The results show that IFRS compliance is value relevant. The implication of this is that IFRS based financial statements of Ghanaian banks are able to capture accounting data relevant to predicting shareholders' wealth of banks in Ghana. Though the multivariate predictive models of all the IFRS constructs appeared significant, IFRS accounting quality which is one of the most widely cited construct of IFRS compliance is found to be irrelevant in this paper.

The evidence of irrelevant accounting quality in the multidimensional models suggests weakness in some recognition and measurement criteria of IFRS. National accounting regulators should tread cautious on the wholesome adoption of IFRS. Future researchers could investigate the value relevance of IFRS accounting quality further at individual IFRS level so as to unearth those specific recognition and measurement criteria which may undermine the overall value relevance of IFRS accounting quality. It is also possible that the choice of measurement of accounting quality might have caused the low value relevance; therefore, future researchers could undertake the investigation using different method of measurement. The value relevance studies only show the predictive power whose effect can either be adverse or economic benefits, it is therefore recommended that future researchers should use the multidimensional model for IFRS compliance estimation to investigate the direction of the value relevance of each of the IFRS constructs.

\section{References:-}

1. Abd-Elsalam, O. H., \& Weetman, P. (2003). Introducing international accounting standards to an emerging capital market: Relative familiarity and language effect, with a case study of Egypt. Journal of International Accounting, Auditing and Taxation, 12 (1), 63-84.

2. Access Bank, Plc (2010). The Implication of IFRS Adoption. A Communiqué of Business Day,9 (186), $34-$ 37.

3. Adetunji, S. A (2016) The value relevance of earnings in the return-earnings relation in the Nigerian Deposit Money Banks. Cogent Business \& Management Armstrong, C., M. Barth, A. Jagolinzer, \& E. Riedl. (2007). Market reaction to the adoption of IFRS in Europe. Working paper, Stanford University Babalola, Y. A. (2012). Significance of Accounting Information on Corporate Values of Firms in Nigeria. Research Journal in Organizational Psychology \& Educational Studies, 1, 105-113.

4. Barth, M. E., Beaver, W. H., \& Landsman, W. R. (2001). The relevance of the value relevance literature for financial accounting standard setting: Another view. Journal of accounting and economics, 31, 1-41 Bartov, E., Goldberg, S., \& Kim, M. (2005). Comparative Value Relevance Among German, US, and International Accounting Standards: A German Stock Market Perspective, Journal of Accounting, Auditing \& Finance, 20(2), 95-119.

5. Beaver, W., Kettler, P., \& Scholes, M (1970), Association between Market-Determined and AccountingDetermined Risk Measures. Accounting Review Benzacar, K. (2008). IFRS: The Next Accounting Revolution. A Publication of CMA Management Choi, D., \& Meek, K. (2007). International Accounting. Prentice Hall.

6. Choi, F.D.S. (1973). Financial Disclosure and Entry to the European Capital Market. Journal of Accounting Research; 11 (2): $159-179$

7. Garuba, O. A (2011). The Challenges of Adopting International Financial Reporting Standards in Nigeria, JORIND, 9(1), 313-319

8. Heidi, H. (2014). Accounting Quality and Terms of Debt: Evidence from IFRS Firm Masters thesis: Aalto University

9. Iyoha, F.O \& Faboyede, S.O. (2011). Adopting International Financial Reporting Standards (IFRS) - A Focus on Nigeria. International Journal of Research in Commerce and Management. 2(1), 35-40.

10. Kunle, O. A., Omoruyi, E. P., \& Hamed, A. B. (2011) Impact of International Reporting Standards on Insurance Management in Nigeria, Middle Eastern Finance and Economics. Eurojournal Publishing, 2, 128142

11. Nermeen, F. S.,(2014). Theories and Determinants of Voluntary Disclosure. Accounting and Finance Research Vol. 3, No. 1; 2014. 
12. Okpala, K. E (2012) Adoption of IFRS and Financial Statements Effects: The Perceived Implications on FDI and Nigeria Economy. Australian Journal of Business and Management Research, 2(5), 76-83

13. Paglietti, P. (2009). Investigating the Effects of the EU Mandatory Adoption of IFRS on Accounting Quality: Evidence from Italy. International Journal of Business and Management, 4, 3-18.

14. Queku, I. C. (2016) Review of Compliance Measure in Empirical Accounting Literature: Perspective of International Financial Reporting Standards. Research Journal of Finance and Accounting, 7(14), 59-66

15. Queku, I. C. (2017) Empirical Test of Multidimensional Model for Estimating International Financial Reporting Standards (IFRS) Compliance: Perspective of Ghanaian Banks.

16. Tsalavoutas, I. (2009). The Adoption of IFRS by Greek listed companies: Financial Statement Effects, Level of Compliance and Value relevance. PhD thesis: The University of Edinburgh. 